\title{
The experimental set for in situ research of benthic communities in marine and freshwater ecosystems
}

\author{
Ryszard Kornijów*, Aleksander Drgas and Krzysztof Pawlikowski \\ National Marine Fisheries Research Institute, Kołłątaja 1, 81-332 Gdynia, Poland
}

\begin{abstract}
The presented system of experimental trays permits conducting field experiments at considerable depths, all year round, and with no application of diving techniques. The deployed set can be entirely hidden under water, which is an advantage in crowded areas. The set is composed of single units, each composed of a tray filled with a substrate, four-legged bridles, and a hanging rope with a removable marker float fixed on top by means of a carabiner clip. The float provides information on the location of deployed trays, and permits proper distribution of next trays to be deployed. After deployment from a boat, the units are connected with a rope, extended on one end by a sinking retrieval rope. The floats are removed immediately after deployment. Any number of units can be deployed to the bottom. It depends on the experimental design and the number of replicates. Retrieval of the set starts with locating the trays by means of GPS, and searching for the retrieval rope by means of a grappling hook dragged behind the boat. Based on our own experience and the literature, the possibilities of development of the described system are proposed depending on the local field conditions and research objectives.
\end{abstract}

Keywords: field experiment / sediments / trays / macroinvertebrates / hydrophytes

Résumé - Un dispositif expérimental pour la recherche in situ sur les communautés benthiques dans les écosystèmes marins et d'eau douce. Le dispositif de plate-forme expérimentale présenté permet de réaliser des expériences de terrain à des profondeurs considérables, toute l'année, et sans besoin de techniques de plongée. L'ensemble déployé peut être entièrement caché sous l'eau, ce qui est un avantage dans les zones fréquentées. L'ensemble est composé d'unités simples, chacune composée d'un plateau rempli d'un substrat, avec une corde à chaque coin avec boucle, et d'une corde de suspension avec un flotteur marqueur amovible fixé au moyen d'un mousqueton. Le flotteur fournit des informations sur l'emplacement des plateaux déployés et permet une distribution correcte des plateaux successifs à déployer. Après le déploiement depuis un bateau, les unités sont reliées par une corde, prolongée à une extrémité par une corde de récupération lestée. Les flotteurs sont retirés immédiatement après le déploiement. Un nombre quelconque d'unités peut être déployé sur le fond. Cela dépend de la conception expérimentale et du nombre de répétitions. La récupération de l'ensemble commence par la localisation des plateaux au moyen du GPS et la recherche de la corde de récupération au moyen d'un crochet traîné derrière le bateau. Sur la base de notre propre expérience et de la littérature, les possibilités de développement du système décrit sont proposées en fonction des conditions locales de terrain et des objectifs de recherche.

Mots-clés : expérimentation de terrain / sédiment / essais / macroinvertébrés / hydrophytes

\section{Introduction}

Experimental techniques are emphasized as powerful research tools providing ecologists with methods for examining patterns, the role of various processes in natural systems, and testing concepts and theories (Resetarits, 1995; McQuaid, 1998; Underwood et al., 2000; Gardner et al., 2001; Srivastava

* Corresponding author: rkornijów@mir.gdynia.pl et al., 2004; Petersen and Englund, 2005; Petersen et al., 2009). In order to be an efficient research method, the experiment must be carefully planned and conducted in a proper scale of time, space and complexity (Petersen et al., 1999, 2009; Chapman, 2000).

Many field experiments in a littoral zone have been conducted, involving the installation of various types of cages, boxes or limnocorrals, both in marine (de Wilde, 1990; Lasserre, 1990; Petersen et al., 2009; Crespo et al., 2017) and freshwater lentic ecosystems (Hall et al., 1970; Kajak, 1970; 
Schindler, 1973; Virnstein, 1978; Werner et al., 1983; Lundgren, 1985; Sih et al., 1985; Wilson, 1990; Tolonen et al., 2001; Kornijów et al., 2005, 2016; Compte et al., 2011; Matuszak et al., 2014). In deeper places, microcosms in the form of experimental trays are increasingly frequently applied, especially in marine environments. The trays, filled with sediment, defaunated or inhabited with a specified number of organisms, are placed on the lake or ocean bed, and sampled over time. This approach was probably applied for the first time by Andrews (1966) during his research on the mortality of oysters.

Conducting an experiment at high depths in both inland and marine waters poses two serious problems requiring a solution: (i) manner of installation of the set on the bottom and its retrieval, (ii) marking and later finding the place in which the set is left for the duration of the experiment, which may last several weeks, months or even years. The former problem can be solved by means of diving (Snelgrove et al., 1992, 2001; Kajak and Dusoge, 1996; Wu and Shin, 1997; Ma, 2005; Werner and Rothhaupt, 2008; Kern et al., 2014; FernandezGonzalez et al., 2016; Sokołowski et al., 2017). However, it is not possible in some conditions (e.g. due to low water transparency or safety requirements). Moreover, the involvement of divers in field experiments complicates research in terms of logistics, and usually increases their costs. The solution for the latter problem can be attaching the experimental installation to a marker float. This in turn becomes problematic when the number of trays is high (sometimes even several tens), and the area is extensively used. Moreover, floats frequently attract attention of curious people, resulting in damaging or destruction of the experiment.

In this paper, we present a simple system of experimental trays permitting conducting field experiments at considerable depths, all year round, and with no application of diving techniques. After deploying the system to the bottom, it can be entirely hidden under water.

The way of deployment and retrieval of trays proposed in this paper has not been described in the literature so far. First, the design of the set is described. Then, based on our own experience and the literature, the possibilities of the development and adaptation of the system are discussed, depending on the stated hypotheses and field conditions.

\section{Technical description}

The experimental set is composed of single units, each composed of a tray, four-legged bridles, and a hanging rope, with a carabiner clip on both ends (Fig. 1). Plastic boxes for fish applied in fishery are used as trays, with the following dimensions: $49 \mathrm{~cm}$ length; $37 \mathrm{~cm}$ width; $15 \mathrm{~cm}$ depth, and a surface area of $0.1813 \mathrm{~m}^{2}$. According to our experience, on the one hand, such dimensions permit relatively easy operation of the trays, and on the other hand, ensure sufficient surface area for conducting experiments even with relatively large organisms. Additional advantages of such boxes are their availability and strong structure.

The lower carabiner clip on the hanging rope permits quick unfastening of the bridles. This facilitates access to the inside of the trays. The upper carabiner clip connects the rope with the marker floats (plastic bottles can be used for this



Fig. 1. Experimental unit, consisting of a tray, four-legged bridles and a hanging rope with a carabiner clip at both ends.

purpose). The length of the hanging rope is higher by approximately $1 \mathrm{~m}$ than the depth at which the experiment is conducted.

Numbered trays are filled with an artificial or natural substrate, e.g. sediment, stones or rocks and then inhabited with experimental plants or animals. Depending on the objective of the research, the trays can be deposited on the bottom either uncovered or covered with mesh (predation or herbivory experiment) (Fig. 2). Such a system allows for deployment of any number of units. It depends on the experimental design and the number of replicates, as well as on whether the trays are supposed to be periodically retrieved for the purpose of sampling and again deployed to the bottom (monitoring), or each time a part of the trays will be retrieved permanently (sampling).

Deployment of trays to the bottom and their retrieval from water requires the involvement of three persons: two for the operation of the set and one for manoeuvring the boat. The sequence of placing the trays on the bottom is as follows (Fig. 3):

- Deploy selected experimental units to the bottom in random order by means of the hanging rope with marker floats attached to the upper carabiner clips. After deployment, the floats provide information on the location of the deployed trays and permit the distribution of the trays at appropriate distances from each other and in the planned direction in relation to the shoreline.

- After deployment of all trays, connect the upper carabiner clips attached to marker floats with the leading rope by means of sailing knots (e.g. loop or clove hitch knots) made on a current basis.

- Connect the end of the leading rope to the several tens of meters long sinking retrieval rope with threaded weights and spread the retrieval rope on the bottom. The rope will later facilitate finding the set on the bottom by means of the 

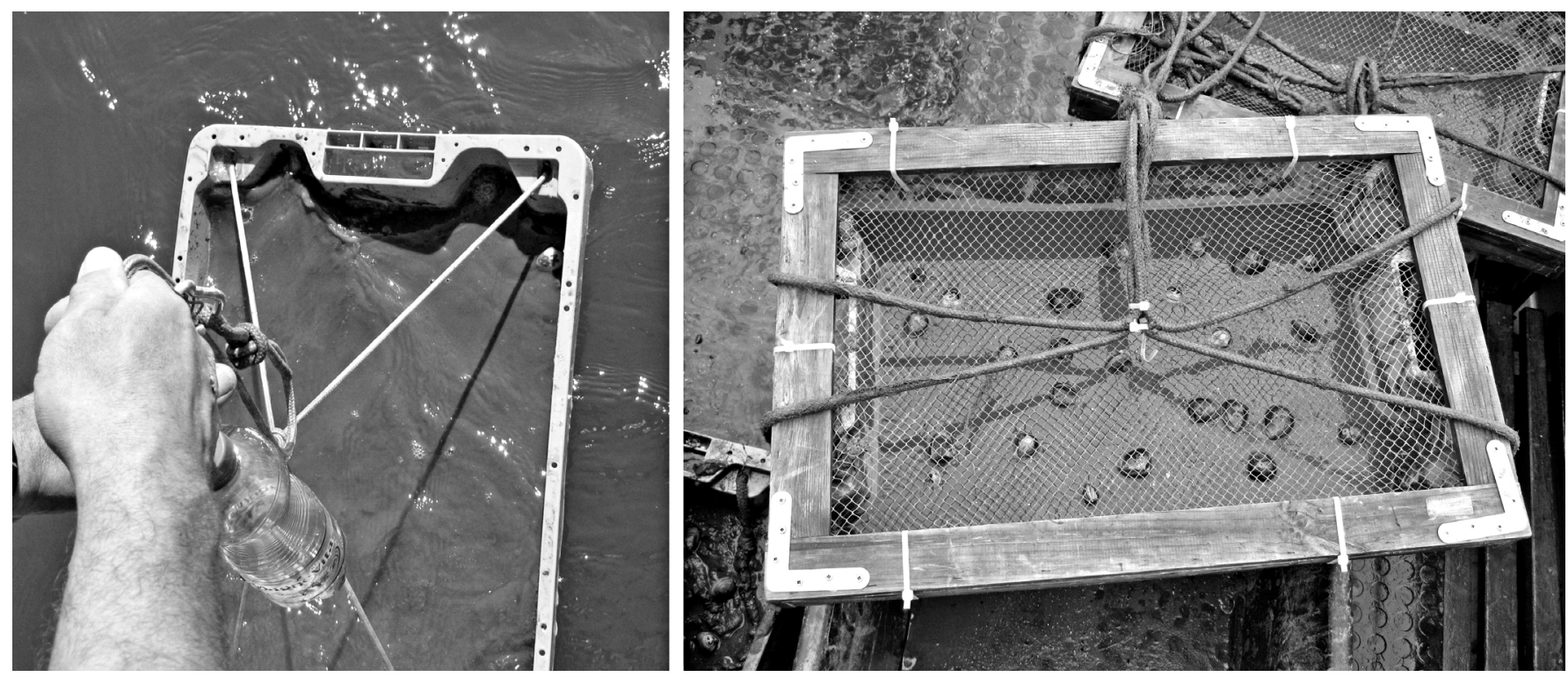

Fig. 2. Experimental trays ready for deployment. On the left - an open tray, on the right - a tray covered with anti-predatory mesh.
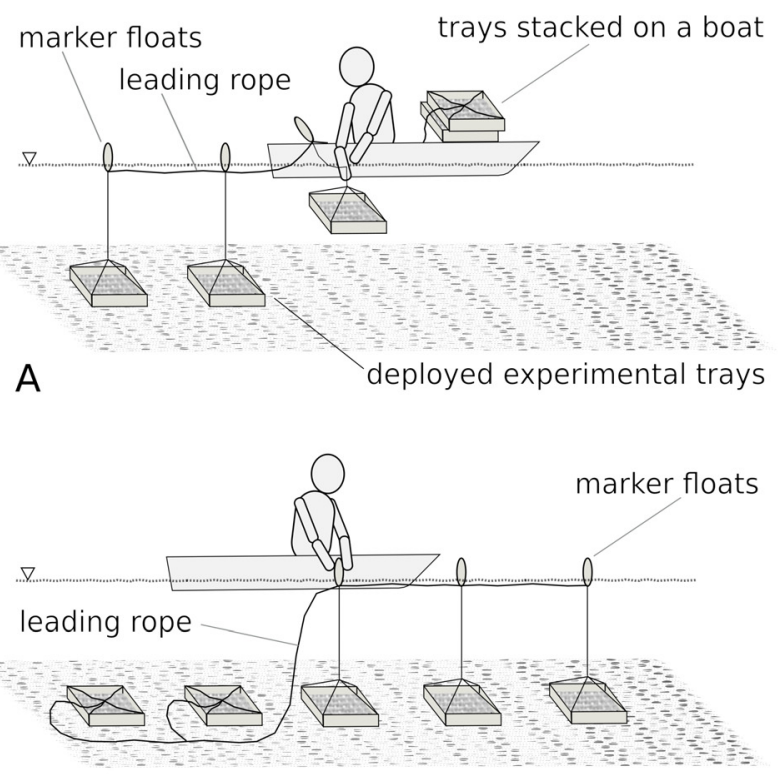

B

$\nabla$

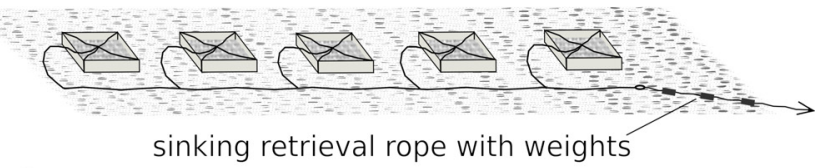

C

Fig. 3. Handling the experimental set; A. Sequence of deployment of experimental units, B. Detaching marker floats, C. The set after detaching marker floats, sunken for the duration of the experiment. grappling hook. The grappling hook, in some centers used for qualitative sampling of submerged macrophytes, is particularly efficient (Fig. 4).

- Detach consecutive floats from the upper carabiner clips of the hanging ropes, drag the leading rope aside as far as possible from the line of the deployed trays (so that after sinking, the leading rope does not lie on the trays), and allow the entire system of ropes to sink.

The recovery of the trays from the bottom occurs in the opposite order. The activity should begin with determining the location of the experiment by means of GPS. Then, the sinking retrieval rope lying on the bottom should be found by means of a grappling hook dragged on the bottom behind the boat. After finding the retrieval rope, find the leading rope, and then consecutive experimental units, and attach marker floats to the upper carabiner clips of the hanging ropes. This facilitates the reconstruction of the current positions of trays. Carefully detach the trays from the bottom, and retrieve them to the boat.

Preliminary works related to the collection and preparation of the sediment, as well as filling trays with sediment, should be preferably performed on shore or on board of a large research vessel. The deployment/retrieval of trays as an activity requiring high precision is easier to perform by means of a small three- to four-manned paddle or motor boat. During deployment and retrieval of the trays from the bottom, it is important for the boat not to move, i.e. not to float over the trays, or drag them behind. Therefore, during such activities, the boat must remain in a strictly specified position. Reaching the place of deployment/retrieval of consecutive trays requires precise manoeuvring of the boat. Meeting such conditions is possible even in strong wind owing to anchoring the boat with the bow upwind by means of two anchors located at an angle of approximately $90^{\circ}$ (Fig. 5). The anchor ropes should have a length at least five or even ten times higher than the depth, 


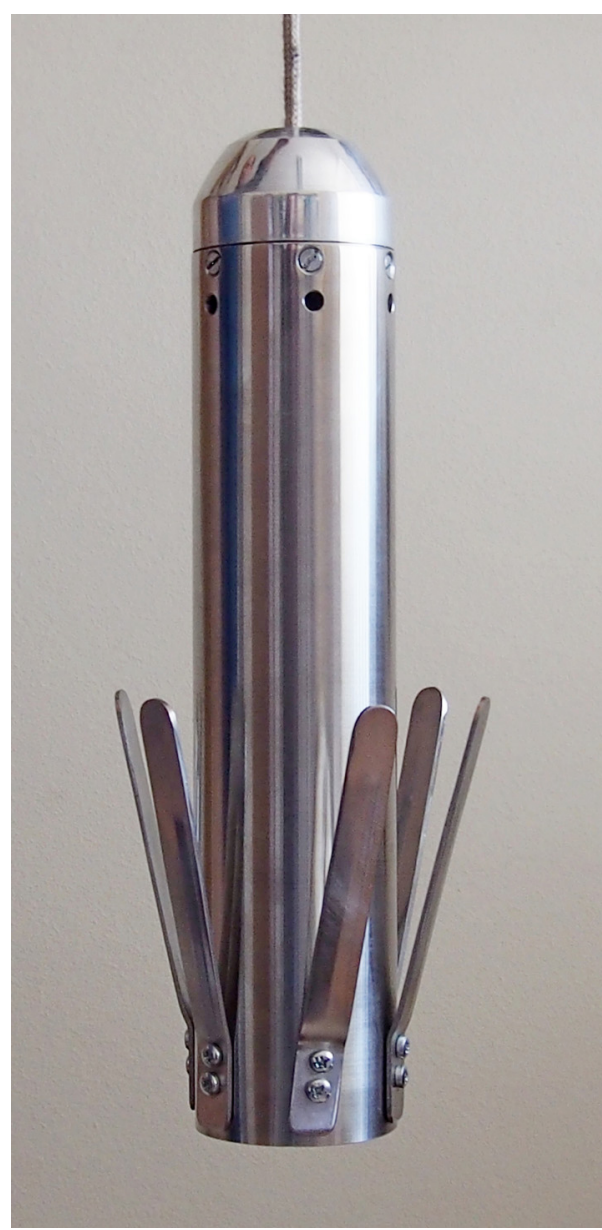

Fig. 4. Grappling hook used for searching for the retrieval rope.



Fig. 5. Method of keeping the boat at the point and precise manoeuvring of the boat with two anchors.

depending on the length of the section over which the trays are distributed. The longer the section, the longer the anchor ropes should be. Movement of the boat occurs by means of reducing or increasing the length of one of the anchor ropes.

\section{Current experience in the application of the experimental set}

We have been applying the described system continuously since the spring of 2014. The objectives of the experiments were to determine growth, survivorship, and predation- and non-predation-driven mortality of invasive mussel Rangia cuneata (G. B. Sowerby I, 1832) in the Vistula Lagoon (South Baltic). We exposed the trays with sediment and mussels in places free of submerged vegetation at a depth of 1.5-2 m, both on hard bottom (sand with only $3 \mathrm{~cm}$ thick layer of silt) and very soft organic sediments. The experiments were conducted all year round. Twice the system was left on the bottom in late autumn and recovered in spring, next year. During vegetative seasons, it was deployed and retrieved every six weeks. Altogether, 6-12 trays were deployed and successfully retrieved each time. We lost two trays on only one occasion - the leading rope was probably cut by someone, and the trays stolen.

\section{Recommendations and conclusions}

Until now, a common practice to mark the location of a deployed tray involved attaching a small float to each tray (Bruesewitz et al., 2009; Pardo et al., 2010). This becomes problematic when the number of trays is high (sometimes even several tens), and the area is extensively used. In the first year of year-round experimental research in the Vistula Lagoon, we fastened the retrieval rope to a chain approximately $0.5 \mathrm{~m}$ under the water surface leading from a marker buoy to the heavy anchor. In the following year, the buoy was only used as a reference point for the place of deployment of the system, and the retrieval rope was searched for by means of a grappling hook. In the third year, we completely abandoned marking the places by means of buoys. Before retrieval, the location of the set was determined by means of GPS, and the retrieval rope was recovered by means of a grappling hook dragged behind the motor boat. Finding the retrieval rope this way usually took from several to a dozen minutes. The final selection of the way of leaving the system (marked with a buoy or entirely hidden under water) should depend on the local conditions. Marking with buoys obviously facilitates finding the system, while hiding it under water reduces the risk of its damage/theft. The occurrence of heavy macrophytes growth (frequent in shallow places) may preclude using a hook for locating the system. In such a case, attaching the leading rope to a marker buoy seems to be the only effective solution.

Owing to the relatively large dimensions, after filling with bottom sediments and deployment, our trays were not moved by water currents in spite of placing the trays at a depth of only $1.5-2 \mathrm{~m}$ (the Baltic Sea is not tidal) and periodical occurrence of very strong winds. No cases of tipping over of trays were recorded. However, taking into consideration the size of trays and relatively light weight in their current form, they can find the best application in locations with low wave energy and currents. In the case of application of trays with small sizes, as well as in high-energy subtidal environments with a considerable risk of damage and loss, the trays can be secured on the surface of the sea bed by means of additional weight or another type of protection. For this purpose, Wu and Shin (1997) applied plastic pegs anchoring the trays in deep sediment, but the solution proved insufficient during a typhoon.

The advantage of using smaller and shallower trays is the easiness of placing them onto sediments in such a way that their upper edges do not protrude above the level of the surrounding sediments. This permits avoiding hydrodynamic 
disturbances affecting the process of colonization of the sediments by organisms (Hulberg and Oliver, 1980; Eckman, 1983; Gallagher et al., 1983; Snelgrove et al., 1992; Snelgrove, 1994). To place trays flush with the ambient sea floor, however, is difficult even for a diver if the sediments are hard.

It is worth paying attention to the length of the bridles applied for attaching the trays. The bridles should be as short as possible. If they are too long, they can get under one of the corners of the tray, resulting in its tipping. As suggested by Olsgard (1999), in order to keep the bridles away from the sediment surface in the trays during the experiment, small underwater floats can be used, fixed to the lower carabiner clips attached to the hanging rope of each of the experimental units. Then, the bridles together with the leading rope will remain slightly above the trays instead of resting directly on them.

The trays can be filled with sediment containing natural plant communities or invertebrate fauna, or inhabited, e.g. with a specified number of organisms. The choice between intact or homogenous sediments should depend on the research questions asked (Petersen et al., 2009). In experiments concerning contamination and colonization of sediments by invertebrates, defaunated sediment is applied, e.g. by means of freezing (Snelgrove et al., 1992, 1999, 2001; Snelgrove, 1994; Ma, 2005; Fernandez-Gonzalez et al., 2016), overdrying (Lu and Wu, 1998, 2000), or a microwave (Kern et al., 2014). The trays can be also filled with hard substrate, e.g. with rocks for colonization or together with attached fauna (Bruesewitz et al., 2009).

The deployment of the trays to the bottom and their retrieval may cause intensive washing out of sediments. If mussels with solid and heavy shells are used in the experiment, such a problem does not exist, but in the case of small benthic organisms, their loss may occur. Sediment loss during deployment can be prevented by sediment freezing (Olsgard, 1999) or by using tray covers (Snelgrove et al., 1992, 1999; Snelgrove, 1994; Ma, 2005; Kern et al., 2014; FernandezGonzalez et al., 2016). However, as admitted by Snelgrove et al. (1992), covering trays under water may cause an impact wave that disturbs the water flow over trays. Wu and Shin (1997) sealed the trays individually in plastic bags on the sea bottom to prevent sediment loss during their retrieval. This, however, is only possible in the case of relatively small trays. In certain conditions, it may cause additional difficulties resulting from the resuspension of sediments and low visibility. During sealing of the trays with plastic bags, washing out of sediments from the trays will certainly occur. A better solution, although requiring the involvement of a diver, seems to be sliding a tray into a large bag made of mesh (Werner and Rothhaupt, 2008). The only so far seemingly efficient solution securing trays against washing out of sediments, not requiring cooperation with a diver, was proposed by Pardo et al. (2010). They equipped the trays with a mechanism that automatically covers them during deployment and retrieval but exposes them while at rest on the sea bed. The solution is sufficiently universal to be applied for various types of experimental trays, also those described in this paper.

It is sometimes needed to collect sediment samples from trays during the experiment ( $\mathrm{Lu}$ and $\mathrm{Wu}, 1998)$. Attention should be paid to the fact that after their retrieval to the surface without covering them beforehand, the surface layer of the sediment, frequently the most abundantly inhabited by fauna, can be easily washed off. Therefore, it seems to be a good solution to collect samples when the trays are still located several centimeters under water by means of several short tubes inserted in the sediment and closed from the top with a cork. The tubes can be retrieved from the trays after retrieving the trays from water and placing them on board.

Concluding, the advantages of the described set of trays are as follows: (i) its application is simple and fast, even under bad weather conditions, (ii) it permits conducting the experiment in places intensively frequented by sailors, fishermen, or anglers, (iii) it can be deployed where it is unsafe or impractical to dive, e.g. in high turbidity estuaries, at a depth up to several meters. It should be taken into consideration, however, that deployment and retrieval of the system (and particularly finding it by means of a hook) will become more and more difficult with increasing depth, (iv) it can be completely hidden under the water, and therefore safe from curious people, (v) it can be filled with a variety of natural or artificial substrates, (vi) it is a kind of open system, i.e. it can be developed in various ways, e.g. the trays can be covered with mesh to exclude or enclose predators, or equipped with a self-cover mechanism to prevent the loss of the sample during deployment or retrieval, (vii) the trays can be sampled safely before being completely recovered from the water.

Although the system described in this paper was designed (and tested) with experimental research on the ecology of mussels in mind, it seems to be applicable to a wide variety of other issues regarding the ecology of both plant and animal benthic communities, such as colonization, habitat preferences, succession, competition, herbivory, or mortality.

Acknowledgments. The work was conducted as a part of statutory activities of the National Marine Fisheries Research Institute, project number P3-7. The authors are grateful to Dr. Leszek Błędzki, Mount Holyoke College, USA, for his constructive comments at the early stage of the manuscript.

\section{References}

Andrews JD. 1966. Oyster mortality studies in Virginia.V. Epizootiology of MSX a protistan pathogen of oysters. Ecology 47: 19-31.

Bruesewitz DA, Tank JL, Hamilton SK. 2009. Seasonal effects of zebra mussels on littoral nitrogen transformation rates in Gull Lake, Michigan, USA. Freshwater Biol 54: 1427-1443.

Chapman MG. 2000. Poor design of behavioural experiments gets poor results: examples from intertidal habitats. J Exp Mar Biol Ecol 250: 77-95.

Compte J, Gascon S, Quintana XD, Boix D. 2011. Fish effects on benthos and plankton in a Mediterranean salt marsh. $J$ Exp Mar Biol Ecol 409: 259-266.

Crespo D, Martinho F, Pardal MA, Dolbeth M. 2017. Survival of Corbicula fluminea (Müller, 1774) in a natural salinity and temperature gradient: a field experiment in a temperate estuary. Hydrobiologia 784: 337-347.

de Wilde PAWJ. 1990. Benthic mesocosms: I. Basic research in softbottom benthic mesocosms. In: Lalli CM, ed. Enclosed experimental marine ecosystems: A review and recommendations. New York: Springer-Verlag, pp. 109-121.

Eckman JE. 1983. Hydrodynamic processes affecting benthic recruitment. Limnol Oceanogr 28: 241-257.

Fernandez-Gonzalez V, Martinez-Garcia E, Sanchez-Jerez P. 2016. Role of fish farm fouling in recolonisation of nearby soft-bottom habitats affected by coastal aquaculture. J Exp Mar Biol Ecol 474: 210-215. 
Gallagher ED, Jumars PA, Trueblood DD. 1983. Facilitation of softbottom benthic succession by tube builders. Ecology 64: 1200-1216.

Gardner RH, Kemp WM, Kennedy VS, Petersen JE, eds. 2001. Scaling relations in experimental ecology. New York, Chichester, West Sussex: Columbia University Press.

Hall DJ, Cooper WE, Werner EE. 1970. Experimental approach to production dynamics and structure of freshwater animal communities. Limnol Oceanogr 15: 839-928.

Hulberg LW, Oliver JS. 1980. Caging manipulations in marine softbottom communities - importance of animal interactions or sedimentary habitat modifications. Can J Fish Aquat Sci 37: 1130-1139.

Kajak Z. 1970. Analysis of the influence of fish on benthos by the method of enclosures. In Kajak Z, Hillbricht-Ilkowska A, eds. Productivity problems of freshwaters. In: Proceedings of the IBPUNESCO Symposium, Kazimierz Dolny, Poland, pp. 323-347.

Kajak Z, Dusoge K. 1996. Substantial increase of Chironomus abundance obtained in field experiment. Int Rev Ges Hydrobiol 81: 469-480.

Kern Y, Rodrigues AR, Absher TM. 2014. Colonization of soft sediments by benthic communities: An experimental approach in Admiralty Bay, King George Island. J Exp Mar Biol Ecol 453: $1-12$.

Kornijów R, Vakkilainen K, Horppila J, Luokkanen E, Kairesalo T. 2005. Impacts of a submerged plant (Elodea canadensis) on interactions between roach (Rutilus rutilus) and its invertebrate prey communities in a lake littoral zone. Freshwater Biol 50: 262-276.

Kornijów R, Measey GJ, Moss B. 2016. The structure of the littoral: Effects of waterlily density and perch predation on sediment and plant-associated macroinvertebrate communities. Freshwater Biol 61: $32-50$.

Lasserre P. 1990. Marine microcosms: small-scale controlled ecosystems. In: Lalli CM, ed. Enclosed experimental marine ecosystems: a review and recommendations. New York: SpringerVerlag, pp. 20-60.

Lu L, Wu RSS. 1998. Recolonization and succession of marine macrobenthos in organic-enriched sediment deposited from fish farms. Environ Pollut 101: 241-251.

Lu L, Wu RSS. 2000. An experimental study on recolonization and succession of marine macrobenthos in defaunated sediment. Mar Biol 136: 291-302.

Lundgren A. 1985. Model ecosystems as a tool in freshwater and marine research. Arch Hydrobiol, Suppl 70: 157-196.

Ma HG. 2005. Spatial and temporal variation in surfclam (Spisula solidissima) larval supply and settlement on the New Jersey inner shelf during summer upwelling and downwelling. Estuarine Coastal Shelf Sci 62: 41-53.

Matuszak A, Mortl M, Quillfeldt P, Bauer HG. 2014. Macrophyteassociated macroinvertebrates as an important food source for wintering waterbirds at Lake Constance. Limnology 15: 69-76.

McQuaid CD. 1998. The role of experiments in ecology. S Afr J Sci 94: 251-254.

Olsgard F. 1999. Effects of copper contamination on recolonisation of subtidal marine soft sediments - an experimental field study. Mar Pollut Bull 38: 448-462.

Pardo LM, Cardyn CS, Mora P, Wahle RA. 2010. A new passive collector to assess settlement rates, substrate selection and predation pressure in decapod crustacean larvae. J Exp Mar Biol Ecol 393: 100-105.
Petersen JE, Englund G. 2005. Dimensional approaches to designing better experimental ecosystems: a practitioners guide with examples. Oecologia 145: 216-224.

Petersen JE, Cornwell JC, Kemp WM. 1999. Implicit scaling in the design of experimental aquatic ecosystems. Oikos 85: 3-18.

Petersen JE, Kennedy VS, Dennison WC, Kemp WM, eds. 2009. Enclosed experimental ecosystems and scale: Tools for understanding and managing coastal ecosystems. New York: Springer-Verlag.

Resetarits WJ. 1995. The role of experiments in ecology. Science 270: 561-562.

Schindler DW. 1973. Experimental approaches to limnology overview. J Fish Res Board Can 30: 1409-1413.

Sih A, Crowley P, Mcpeek M, Petranka J, Strohmeier K. 1985. Predation, competition, and prey communities - A review of field experiments. Annu Rev Ecol Syst 16: 269-311.

Snelgrove PVR. 1994. Hydrodynamic enhancement of invertebrate larval settlement in microdepositional environments - colonization tray experiments in muddy habitat. J Exp Mar Biol Ecol 176: 149-166.

Snelgrove PVR, Grassle JF, Petrecca RF. 1992. The role of food patches in maintaining high deep-sea diversity - field experiments with hydrodynamically unbiased colonization trays. Limnol Oceanogr 37: 1543-1550.

Snelgrove PVR, Grassle JP, Grassle JF, Petrecca RF, Ma HG. 1999. In situ habitat selection by settling larvae of marine soft-sediment invertebrates. Limnol Oceanogr 44: 1341-1347.

Snelgrove PVR, Grassle JF, Grassle JP, Petrecca RF, Stocks KI. 2001. The role of colonization in establishing patterns of community composition and diversity in shallow-water sedimentary communities. J Mar Res 59: 813-830.

Sokołowski A, Ziółkowska M, Balazy P, Plichta I, Kukliński P, Mudrak-Cegiołka S. 2017. Recruitment pattern of benthic fauna on artificial substrates in brackish low-diversity system (the Baltic Sea). Hydrobiologia 784: 125-141.

Srivastava DS, Kolasa J, Bengtsson J, Gonzalez A, Lawler SP, Miller E, Munguia P, Romanuk T, Schneider DC, Trzcinski MK. 2004. Are natural microcosms useful model systems for ecology? Trends Ecol Evol 19: 379-384.

Tolonen KT, Hamalainen H, Holopainen IJ, Karjalainen J. 2001. Influences of habitat type and environmental variables on littoral macroinvertebrate communities in a large lake system. Arch Hydrobiol 152: 39-67.

Underwood AJ, Chapman MG, Connell SD. 2000. Observations in ecology: You can't make progress on processes without understanding the patterns. J Exp Mar Biol Ecol 250: 97-115.

Virnstein RW. 1978. Predator caging experiments in soft sediments: caution advised. In: Wiley ML, ed. Estuarine interactions. New York: Academic Press, pp. 261-273.

Werner S, Rothhaupt KO. 2008. Effects of the invasive Asian clam Corbicula fluminea on benthic macroinvertebrate taxa in laboratory experiments. Fund Appl Limnol 173: 145-152.

Werner EE, Gilliam JF, Hall DJ, Mittelbach GG. 1983. An experimental test of the effects of predation risk on habitat use in fish. Ecology 64: 1540-1548.

Wilson WH. 1990. Competition and predation in marine softsediment communities. Annu Rev Ecol Syst 21: 221-241.

Wu RSS, Shin PKS. 1997. Sediment characteristics and colonization of soft-bottom benthos: a field manipulation experiment. Mar Biol 128: 475-487.

Cite this article as: Kornijów R, Drgas A, Pawlikowski K. 2017. The experimental set for in situ research of benthic communities in marine and freshwater ecosystems. Knowl. Manag. Aquat. Ecosyst., 418, 12. 